\title{
Г.X. Зиннатуллина
}

Казанский Наџиональный исследовательский технический университет им. А.Н. Туполева

\section{Типы и функции апеллятивных идентификаторов» (на примере художественных текстов татарской литературы)}

Аннотация: В статье рассматриваются функции и типы нарицательных имен, которые сопровождают имена собственные в тексте. В частности, анализируются этнонимы и различные комплексные наименования.

The paper discusses the functions and types of appellatives (common nouns), that «accompany» proper names in the text. In particular, analysis is made of ethnonyms and various complex names.

Ключевые слова: имена собственные, комплексные наименования, функции, художественный текст.

Proper names, complex names, functions, literary text.

УДК: 811.512 .145

Контактная информация: Казань, ул. К. Маркса, 10. КАИ, кафедра русского и татарского языков. Тел. (843) 2310233. E-mail: www.gulshatzin@bk.ru.

Для обозначения апеллятива в сочетаниях типа девочка Mама в лингвистической литературе встречаются выражения «идентификатор», «квалификатор», «детерминатив», «категориальное существительное». В дальнейшем изложении мы будем пользоваться термином идентификатор. С синтаксической точки зрения речь идет о приложении - разновидности определения, когда в отношении определяющего и определяемого вступают имена существительные. Согласуемое существительное в этом случае может определять другое существительное с разных сторон: по названию (город Москва, месяц март), по функции, назначению (судно-холодильник) и т.П. [Русская грамматика, 1980, с. 57]. Интересующие нас имена собственные, т.е. «названия городов, деревень, гор, рек, озер, пристаней, станций, газет, гостиниц, магазинов, учреждений» в Русской грамматике-80 однозначно относятся к приложениям. К ним же относятся все определения - названия лица собственным именем: девочка Оля, тетя Катя, моя соседка Петренко» [Там же, с. 59]. Кроме того, отмечается, что личные и фамильные имена могут присоединяться к определяемому слову при помощи специальных сочетаний: по имени, по фамилии, по прозванию, по кличке, под именем, под фамилией, под названием.

Для нарицательных существительных, сопровождающих имена собственные (ИС) в тексте, можно также предложить термин апеллятивный конвой (по аналогии с выражениями литературный конвой, эпистолярный конвой). Апеллятивов может быть один или несколько, располагаться они могут как слева (девочка Маша), так и справа (Ленин, вождь мирового пролетариата), а также окружать ИС с обеих сторон (гражданка Голубева, зубной врач).

Рассмотрим некоторые типы и функции апеллятивного конвоя при ИС в тексте. Литературными источниками послужили произведения классиков татарской литературы А. Еники, Ф. Хусни и М. Амира. 


\section{Этнонимы}

Этнонимы как тип идентификаторов (русский Иван, немец Шульи) интересны тем, что их роль в сочетании с ИС полностью раскрывается только в тексте. Так, этноним в препозиции к ИС несет дополнительную информацию и участвует в идентифицировании предмета речи. Наряду с такой нейтральной информативноидентификационной функцией, для этнонимов при ИС в зависимости от типа текста можно обнаружить еще некоторые другие функции, связанные с преодолением как нейтральности, так и прямой информативности.

1. Этноним при ИС может выступать в роли аргументативного контрапункта ${ }^{1}$ при соответствующем развертывании текста. В речевую партию персонажа этноним вводится не для информирования читателя о национальной принадлежности того, о ком идет речь, но для лаконичного и исчерпывающего выражения аргументации с точки зрения этого персонажа. Для сравнения: «Русча акцент беләнрәк сөйләве аны шундук ачып салды: һәрхәлдә, рус кызы түгел иде ул...Әйе, без ялгышмаганбыз: Чуваш педагогия институты студенткасы, чуаш кызы Әлмия...» (Ее речь с русским акцентом тут же выдала ее, во всяком случае она не была русской... Да, мы не ошиблись: студентка Чувашского пед. иститута, чувашская девушка Альмия) [Хусни, 2002, с. 73]. «Тик урыны hаман анын белән яндшә туры килүче чуаш егете Яков кына аңуа шактый Үз булып китә алды» (Только лишь чувашский парень Яков, с которым их места всегда оказывались рядом, пришелся ему по душе) [Амир, 1987, с. 103]. «Тик участок зоотехнигы, бик яхшы татарча белүче яшь чуаш кызы Настя Шубина гына... матур гына бер чblгыш ясадыр (Довольно хорошо выступила лишь зоотехник участка, свободно говорившая на татарском языке молоденькая чувашская девушка Настя Шубина) [Еники, 2001, с. 26]. «Мордва бае Польдяев монда таштан ике катль итеп, ике зур йорт салдырган» (Мордвийский богач Польдяев построил здесь два больших двухэтажных каменных дома) [Еники, 2003, с. 34].

2. Этноним в сочетании с ИС может выступать как инструмент риторического приема амплификации - избыточной развернутости выражения, который используется для усиления речевого воздействия. В роли амплифицирующего средства этнонимов должно быть много, т.е. должна иметь место операция перечисления. В данном фрагменте текста этнонимы семантически привязаны к словосочетанию с географическим смыслом. Если мы попытаемся убрать из перечисления этнонимы, то фигура амплификации исчезнет, а останется лишь не обладающее никаким риторическим эффектом банальное перечисление исторических ИС. Вот строки из произведения А. Еники «Без дә солдатлар идек» («Мы тоже были солдатами»): «...Болар “картлар”, башта ук нестроевой хезмәткә альнган солдатлар: мәсәлән, казакълардан Өметбаев белән Байәхмэтов, үзбәк Иимәмәт, яки менә руслардан Шумилов... Шулай ук безнен арада, алгы сызыкта булыл, сугыш эченндн шактый өтелеп чыкканнар да бар. Шундыйлардан менә Хафиз Акшалов, Дорды Ходайбирдин (икесе дә казаквлар), минем якташлардан Төхфәт абзый белән чуаш Емелькин... Командирлары да миңа яхшы таныши кыргыз егете - Нугайбәк Кулибаев дигэн лейтенант» («Это “старики”, солдаты, которые изначально были призваны для нестроевой службы. Например, из казахов Уметбаев с Баяхметовым, узбек Ишмамат, или вот из русских Шумилов... Также среди нас есть и такие, которые побывали на передовой. Из таких вот Хафиз Акшалов, Дорды Ходайбирдин (оба казахи), из моих земляков Тухфат абзый и чувашин Емелькин... И командир их хорошо мне знакомый киргизский парень лейтенант Нугайбек Кулибаев») [Еники, 2003, с. 247].

Подобное явление наблюдается и в другой повести А. Еники («Вөждан» «Совесть»). Однако в данном примере прием амплификации достигается путем

\footnotetext{
${ }^{1}$ Термин Н.В. Васильевой.
} 
перечисления не этнонимов, а антропонимов. «...Тагын иң кызыгы иунда, бу белгечләрнең күпчелеге, бигрәк тә бөтен каракүлчеләр Мәскәү, Ленинград тирасеннан табыл, чакыртып китерелгән мишәрләр иде... Маматов, Байтирәков, Иимаметов, Ширинский кебек ничектер ихтыярсыздан ихтирам уята торган фамилияләр» («Самое интересное ещё и втом, что большинство их, особенно все специалисты по каракулю, были мишарами, специально приглашенные из окрестностей Москвы и Ленинграда... Маматов, Байтираков, Ишмаметов, Ширинский - фамилии, которые уже подсознательно вызывают уважение») [Еники, 2002, с. 211]. Такое же явление наблюдается и в воспоминаниях А. Еники «Страницы прошлого»: «Бу ашльљны ж⿻ыеп озатучылар арасында зур рус байларын күрәбез: Лашков, Тимофеев, Косториннар...» (Среди работников элеватора мы видим известных русских богачей - Лашкова, Тимофеева, Косторина...) [Еники, 2003, с. 36].

Кроме вышеуказанных случаев, исследователи отмечают еще одну функцию этнонимов в данном сочетании. Этноним может сочетаться с «неподходящими» ИС, т.е. происходит намеренная актуализация этнонима при очевидном несоответствии его и сопровождаемого им собственного имени принятой культурноязыковой норме [Васильева, 2009, с. 41]. Отправитель сообщения подчеркивает, таким образом, свое знание нормы и радуется произведенному эффекту. Ср.: швед Ибрагимов, немец Иван, англичанин Ганс и др. Однако в исследуемых нами произведениях таких примеров обнаружено не было.

Таким образом, для этнонимов как партнеров собственных имен, помимо нейтральной информативно-идентификационной функции можно назвать, по крайней мере, еще три, которые - подчеркнем это, обнаруживаются только в тексте.

\section{Апеллятив + ИС как комплексный знак}

Как комплексный идентифицирующий знак «апеллятив + ИС» выступает в нескольких случаях. Прежде всего, это номинации в военной среде, т.е. номинативный блок «звание + фамилия», поскольку идентификация в данной социальной сфере не предполагает фамилии без звания и звания без фамилии (в отличии от неформального общения). Как показывает анализ исследуемых произведений, подобные конструкции встречаются довольно часто, причем не только в случае с персонажами-военными. Авторы регулярно используют сочетания апеллятивов, указывающих на род деятельности персонажей. Причем апеллятив может быть и в пре- и постпозиции: прокурор Мөхсинов, наводчик Субаев, комиссар Павленко, полковник Ромашкин, капитан Журавлёв, курсант Сидоркин [Амир, 1987, с. 46-58], көтүче (пастух) Сафа [Там же, с. 3], кибетче (продавец) Ярхәм, чана карамалаучы Сабиржан, тегуче (портной) Зариф [Хусни, 2002, c. 321], моторист Касыйм, бригадир Шәймәк, волкомол секретаре Идрисов, волком секретаре Батталов [Там же, с. 226], мәгариф бүлеге мөдире (начальник отдела образования) Касимова [Амир, 1987, с. 46]. Постпозиция: Шакир бай, Сафа купеи, Хәйдәр мәзин, Хафиз хәлфә, Искәндәр ахун.

К комплексным наименованиям в тексте можно отнести и маркеры категории вежливости, т.е. такие слова как господин, госпожа и т.д., которые также называются обращениями. В татарском языке подобных обращений много, и это отчетливо отражается в произведениях. К таким словам можно отнести такие обращения, как апа (апай), түти, абыстай, әби - обращение к женщине старшего возраста, абый (абзый), агай, бабай - обращение к мужчине старшего возраста,

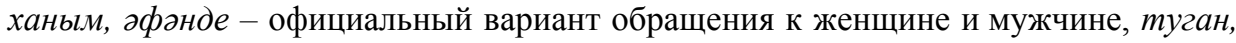
$\partial y c$ (дустым) - обращение к мужчине / женщине, которое несет в себе экспрессивную нагрузку (подчеркивает близость, непринужденность отношений), каениш - обращение к родственникам мужа, акьлльым - обращение, которое чаще 
употребляется по отношению к людям младшего возраста, кияу, ульым - обращение к молодым людям, кызым - обращение к дочери или женщине более молодого возраста, балам, балакай - обращение мужчине / женщине молодого возраста. После Октябрьской революции в лексику татар активно входит обращение иптәш («товарищ»), которое используется в официальном стиле. Вот лишь некоторые примеры из анализируемых произведений: Якуб абзый, Хупжамал абыстай, Баязит агай [Хусни, 2002, с. 32-35], Сәрби әби, Хәйри кияү, Фәрди ульлм [Там же, с. 96], Мөстәкыйм дус, Мәсрүрә түти [Там же, с. 115], иптәи Ибраһимова, иптәш Галләмов, иптәш Карпов [Амир, 1987, с. 34], Патьий әби [Там же, с. 11], Шәмсинур әби, Әхмәтвәли ульм, Локман бабай, Зәйтүнә балакай, Батыржсан дускай [Еники, 2000, с. 89], Гайнүш ханым, Майбәдәр абыстай [Там же, с. 134], Гөлбикә кызым, Суфиян ульмм, Миңлебай бабай [Еники, 2002, с. 18] и др.

Кроме того, в исследуемых текстах часто используется сочетание «күрше (“сосед, соседка") + антропоним». Данная конструкция позволяет еще более конкретизировать персонажа, о котором идет речь, прослеживается уважение говорящего к нему. В результате мы имеем дело с апеллятивным конвоем, окружающим ИС с обеих сторон: «...Күршедәге Нуржсиһн әби дә шулай уйльй» (Соседка Нурджихан аби думает также); «...Tьлшта буран котыра, ... әллә нидә бер күрие Әхми абзыйларның эте өреп куя...» (На улице буран, ... только лишь изредка лает собака соседа Ахми абзый) [Хусни, 2002, с. 18]. «Мәсәлән, безнең уң як күршебез Якуб абзыйларда беркөнне мондый хәл булган» (Например, у наших соседей справа, в семье Якуба абзый однажды случилось следующее...) [Там же, c. 31].

Хотелось бы также отметить, что помимо вышеперечисленных конструкций, очень часто используется сочетание ИС со словами атль, исемле, дигән («по имени»). В результате образуется следующая конструкция: ИС+исемле (атль) + существительное (сам субъект высказывания). Ср.: «Сез минем Рәиит исемле малайны белмисездер әле» (Вы, наверное, еще не знаете моего сына по имени Рашид) [Хусни, 2002, с. 13]. «..Яиьлек тилелеге белэн Зөһрә атль кызга өйләндем» (По молодости женился на девушке по имени Зухра). «Донор дигәннәре Мәдинә атлы яшь хатын булып чыктыл» (Донором оказалась молодая женщина по имени Мадина). «Бераз үсә төшкәч, моңза Фәрит дигән күрше малае өстәлде» (Немного повзрослев, к этому добавился и соседский мальчик по имени Фарид) [Там же, с. 178]. «...Садри дигән егет гармоньда Үзе чьгарган “Колхоз көен” уйнамакчbl» (Молодой человек по имени Садри хотел сыграть на гармони «Мелодию колхоза» собственного сочинения) [Там же, с. 246]. «Мин 1931 елның көзендә Гөлсем исемле сылу гына кызга өйләндем» (Осенью 1931-го года я женился на хорошенькой девушке по имени Гульсум) [Еники, 2003, с. 56]. «Менə шул Нурания атлы нечкә билгә ...mракторчы Галләм килеп сырышкан» (Вот к этой стройяшке по имени Нурания ... «прилип» тракторист Галлям) [Хусни, 2002, с. 78]. «Ул кызчык Сәлимә атлы булыл чыктыл» (Эту девчушку, оказывается, звали Салима) [Там же, с. 201].

Также большой интерес представляют сочетания, в которых лицо, о котором идет речь, характеризуется посредством отношения к другим лицам. Они отражают какие-то родственные отношения, брачный союз и т. д. 1) Апеллятивный конвой, который представляет персонаж через его родителей: «Шул Әсма кызыдыр инде бу, кыланчык!» (Наверное, это дочка Асмы, кривляка!) [К.м.]. «...Күллетүбә авылының Харис малае Рифгать Котльбаев профессор Баев бульпп йөри башлар» (...Сын Хариса из деревни Куллетуба Рифгат Кутлыбаев станет профессором Баевым) [Там же, с. 128]. «Кичэ Сабир кызы Хәдичәдән хат aлдымм» (Вчера получил письмо от Хадичи, дочки Сабира) [Там же, с. 151]. «Жамалыйның уртанчы кызы Зөбәйдә» (средняя дочка Джамали) [Там же, c. 246]. 
2) сочетания, в которых персонаж является чьим-то родителем «...кайдадыр шунда якында гына - Наилнең әтисе» (...где-то там недалеко - папа Наиля) [Хусни, 2002, с. 19]. «Юк, тагын бер кеше - Нураниянең әнисе Маһруйбикә түти булган икән әле» (Нет, оказывается, был еще один человек - мама Нурании тетя Махруйбикэ) [Там же, с. 78]. «hарун Хәйрулловичның анасы Майбддәр карчыкка жчтммеш ящь тула икән» (Матери Харуна Хайруловича оказывается исполняется 70 лет) [Еники, 2000, с. 134].

3) конструкции, в которых персонаж называется посредством супруги (супруга): а) «Хәтта Галиулланың карчыгы Әсхәпжсамал түти дә белмәмешкә сальша» (Даже старушка Галиуллы Асхапджамал притворяется ничего не знающей) [Хусни, 2002, с. 106]. «Председательгә чатта бөкре Хамматша xamblнb Mahuman очрады» (На перекрестке председатель встретил жену горбатого Хамматши Махитап) [Там же, с. 287]. «Яшь мулла хатыны Гайшә абыстай шулай сөйлэп утырдыл» (Так рассказывала жена молодого муллы Гайша абыстай) [Там же, с. 404]. «Сания янында Сөләйман белән аның карчыцы Хафизә генә калдыı» (Рядом с Саниёй остались лишь Сулейман и его старушка Хафиза) [Амир, 1987, с. 58]. б) Случаи, когда герой представляется читателю супругой (супругом), используя категорию принадлежности. «Хатыным Саимэ белән миңяа таныии инде бу озынлык» [Хусни, 2002, с. 84]. «Мин аны, ирем Миркасыймны дйтүем, яратып чыктымм» (Я по любви вышла за своего Миркасыма) [Там же, c. 65].

4) Сочетания, дающие информацию о герое через его брата или сестру: «Гайшә апаның сеңлесе, доктор Үзбәковның балдызы була инде» (Младшая сестра Гайши ханум, свояченица доктора Узбекова) [Еники, 2000, с. 227] «Гыйниятулла абзыйның энесе Искәндәр абзый Мәскәүдә Бауман институтының профессоры иде» (Младший брат дяди Гиниятуллы Искандер был профессором института им. Баумана) [Еники, 2003, с. 48].

Подводя итог, отметим, что для многих типов апеллятивного конвоя при собственных именах их семантика и функции, а также семантика и функции именной группы в целом проявляются только в тексте. Текст выступает одновременно и пространством реализации функций указанных единиц, и средством их поддержки.

\section{Литература}

Васильева Н.В. Собственное имя в мире текста. М., 2009.

Русская грамматика. М., 1980.

Фонякова О.И. Имя собственное в художественном тексте. Л., 1990.

\section{Литературные источники}

Еники Ә. Әсәрләр, 5 томда, 1 том. Казан, 2000.

Еники Ә. Әсәрләр, 5 томда, 2 том: Повестьлар. Казан, 2001.

Еники Ә. Әсәрләр, 5 томда, 3 том. Повестьлар. Казан, 2002.

Еники Ә. Әсәрләр, 5 томда, 4 том: Соңгы китап. Истәлекләр. Казан, 2003.

Хөсни Ф. Сайланма әсәрләр. Казан, 2002.

Әмир М. Әсәрләр: өч томда. 2 том. Казан, 1987. 